\title{
Living with omega-3: new materialism and enduring concerns
}

\section{Sebastian Abrahamsson, Filippo Bertoni, Annemarie Mol}

AISSR, Department of Sociology and Anthropology, Kloveniersburgwal 48, 1012 CX

Amsterdam, the Netherlands; e-mail: c.s.abrahamsson@uva.nl,F.Bertoni@uva.nl, A.Mol@uva.nl

\section{Rebeca Ibáñez Martín}

Instituto de Filosafía-Centro de Ciencias Humanas y Sociales, Madrid, Spain; e-mail: Rebeca.ibanez@cchs.csis.ec

Received 14 April 2014; in revised form 21 July 2014; published online 18 December 2014

\begin{abstract}
In the early 21st century quite a few social scientists and scholars in the humanities are arguing that we should pay more attention to things material. For, as they say, not only humans act but so, too, do materials. Joining this discussion, in this paper we will use the case of omega-3 fatty acids to address the questions of how materials may act; in which ways this is relevant; and what is linked up with it. Hence, we will come to speak about research in prisons where inmates were badly nourished; fish being caught in the Global South for Scandinavian fish pills; and the urgency of shifting from the verb 'to act' to a differentiated list of modes of doing. Learning from the natural sciences, we will argue, requires that their methods and concerns be carefully attended to. Taking matters seriously comes with the obligation of tracing where such matters come from and where they go. And talking about 'action', finally, demands that, beyond liberal notions of isolated individual actors, it be creatively retheorised.
\end{abstract}

Keywords: new materialism, relational materialism, political philosophy, omega-3, fish, science and technology studies

\section{Introduction}

As in the course of the 20th century the social sciences and humanities developed, they sidelined 'nature' and left this to the natural sciences. While the natural sciences were taken to explore the causal links between things material, the social sciences and humanities took it upon themselves to unravel human interactions, institutions, interpretations, ideas, and ideals. ${ }^{(1)}$ In the early 21 st century, however, quite a few social scientists and scholars in the humanities are arguing that 'we', too, should pay more attention to materiality (Bryant et al, 2011; Henare et al, 2007; Alaimo and Hekman, 2007). They say that it is not simply the social conditions for knowing that deserve our attention, but also 'matter itself', the material reality being known. This conviction comes in many versions. Among them is a new materialism in which the call for "a renewed emphasis on materiality" goes together with the insistence that we need "a novel understanding" of materiality (Coole and Frost, 2010, page 5). ${ }^{(2)}$ Materiality should no longer be caught in determinist, causal schemes, but rather explored as something

\footnotetext{
${ }^{(1)}$ For an elegant rendering of this divide and his particular suggestion for how to escape from it, see Latour (2002a).

(2) There are analogous shifts of attention in related bodies of work. A call for attention to matter is also present in the object-oriented ontology movement in philosophy and in the ontological turn in anthropology. Reviewing the differences between these trends and the new materialism is beyond the scope of the present paper, but see Bertoni (2011) and Viveiros de Castro et al (2014). For the very different way 'ontology' figures in the social studies of science, see Woolgar and Lezaun (2013).
} 
that has agency. Talking about agency helps to draw 'materiality' into an agential domain par excellence: that of politics - or political theory. And indeed, political theory should concern itself with the material world. In times of pollution, species extinction, global warming, and so on, this makes eminent sense. But how to attend to matter, which forms might materialism take? In this paper we will argue that the so-called new materialism risks to unduly simplify things. And we will add some complexity, some specificity, to the discussion.

In doing so we join others who have similar concerns. When, in a new materialist vein, political philosopher Jane Bennett (2010) wrote that "everything is, in a sense, alive", geographers Bruce Braun and Sarah Whatmore retorted with the question whether more might not be "gained from a closer attention to the specificity of the matter at hand, as opposed to a generic analogy to 'life' that could be described as a metaphysics" (2010, page xxix). ${ }^{(3)}$ To achieve such specificity, here we will work from a case. In many texts that call for new materialism, cases are strikingly absent, and hence, ironically, 'matter itself' does not appear at all. ${ }^{(4)}$ In this context Bennett's work is interesting to relate to. She, at least, tries to avoid free-floating abstractions. In her book Vibrant Matter she uses examples as diverse as trash, power networks, metals, and food to support her more general claim that things have "the capacity ... not only to impede or block the will and designs of humans but also to act as quasi agents or forces with trajectories, propensities, or tendencies of their own" (2010, page viii). Seeking to criticise the idea that matter is brute, immobile, and passive, Bennett finds food particularly interesting, as, she suggests, "an enhanced alertness to edible matter can contribute to a theory of vital materiality" (2010, page 40). As we happen to study eating practices, this remark raised our curiosity. We decided to borrow our case from Bennett and to explore the particular 'matter' that she mobilises in a paper called "Edible matter" (2007) and once again in a chapter of Vibrant Matter: omega-3.

Omega-3 is fascinating indeed. But Bennett's presentation of this fatty acid's particularities leaves a lot to be desired. Hence, this case offers us an occasion to articulate a few of the relevant desiderata. The first of these has to do with the practices of sciences. Seeking to talk about the agency of omega-3, Bennett finds "support in scientific studies of the effects of dietary fat on human moods and cognitive dispositions" (2010, page 39-40). However, she skips the question of how the 'scientific studies' she alludes to may have found such effects. ${ }^{(5)}$ Here, in contrast, we bring that question to the fore. Informed by decades of work in the social studies of science, we explore the details of the materials and methods sections of the articles quoted. ${ }^{(6)}$ This brings to bear that omega- 3 is not matter itself all by itself, but rather matter in context. It is engaged in many relations.

Our second step is to ask where the edible omega-3 comes from. At this point we will bring in other literatures, for Bennett just quotes research that suggests that, when ingested, omega-3 acts to change 'human mood and cognitive disposition'. However, there is other research that lays out that most of the omega-3 packed in the pills marketed to health-seeking human beings in the Global North comes from fish caught in the Global South. Which implies

(3) And see also Lemke (2014) who, taking his inspiration from Foucault, takes issue with the work of Bennett, Barad, and other new materialists.

${ }^{(4)}$ See, for example, Dolphijn and Van der Tuin (2012) or Connolly (2013) for two recent examples.

${ }^{(5)}$ Much of the literature in new materialism relies on or borrows insights from experimental sciences without acknowledging their situatedness or querying their methods and the transportability of their results. For other examples of this critique, see the great analyses of Leys (2011) and Martin (2013) on the way affect theory draws from biological and behavioural research.

${ }^{(6)}$ The social studies of science are a huge field, and our readings are informed by a diverse literature. But see for inspiration, eg, Latour (1987), Haraway (1991), and Law (2004). The ideal research technique in this field would be to ethnographically study scientists and their practices. However, with a careful text analysis a first layer of practicalities may already be drawn from an article. 
that omega-3's current popularity as a health supplement, whatever its effect in the North, has dire consequences for fish, fish stocks, and poor fishermen in the South. This raises the question which 'actions' of this or that matter (here: omega-3) to foreground.

As a third step, we return to the issue of agency. Bennett is adamant that political theory should attend to vibrant matter because materials, like humans, have agency. And while we fully agree that political theory should, indeed, attend to matter, we have doubts about the 'agency'. First, we are surprised that Bennett talks about omega-3's agential power while drawing on research that investigates its causal effects. Second, we wonder whether it is wise to include ever more members in the formerly exclusive club of 'actors', while silently pushing the study of 'causes' to one side. Instead, we argue here, it might be a better idea to move beyond the agency-versus-causality divide altogether. The case of omega- 3 helps to explore other modes of doing, such as affording, responding, caring, tinkering, and eating. Matters may engage in relations of ever so many kinds.

\section{What omega-3 may do}

Bennett argues that philosophers and social scientists should invest more in studying materialities. Take food, she says. Mostly, if social scientists attend to food at all, they avoid issues to do with its materiality. They:

"mainly focus on human acts in, for example, the rhetoric of culinary self-expression or the socio-cultural rituals and practices through which meaningful food objects are produced, or the aesthetic-commercial techniques through which desire for a new food product is induced. With the exception of the cookbook author or restaurant reviewer who describes the colour, texture and aroma of ingredients, food writing seldom attends to the force of materiality" (Bennett, 2007, page 138).

This remark forms a common ground between us. For along with Bennett we, too, take it that the materialities of food deserve to be explored by researchers of all kinds, social scientists included. The question at stake here is how to go about such explorations.

In her book Vibrant Matter Bennett calls upon food to illustrate that matter is lively, vibrant, and able to display nonhuman agency. But how is food able to do so? Bennett is eager to avoid the banal: "that food can make people larger is a fact so ordinary and obvious that it is difficult to perceive it as an example of a nonhuman agency at work" (2010, page 41). Here we might part company, for in our own research we have learned that the question of how food can make people larger is exceedingly complex and, though maybe ordinary, not obvious at all. There is a lot to learn from studying the seemingly banal. ${ }^{(7)}$ But, that said, let us follow Bennett a little longer and quote her again:

"The case becomes a bit stronger, perhaps, when we learn of hitherto unrecognized powers of dietary fats, in particular their ability to make a qualitative as well as quantitative difference. Several recent studies suggest that fat (not the fat in potato chips, but omega-3 fatty acids prevalent in some wild fish) can make prisoners less prone to violent acts, inattentive schoolchildren better able to focus, and bipolar persons less depressed" (2010, page 41).

In order to talk about the agency of food, Bennett focuses on specific fats: not those in potato chips, but rather those from wild fish; not those that make people larger, but those that make them less violent, better able to focus, less depressed. Bennett draws her knowledge about omega-3 from the scientific literature: a trial that investigated the effects of omega-3 on the aggressive behaviour of prisoners (Gesch et al, 2002); another trial in which children with developmental coordination disorder were given omega-3 supplements (Richardson and Montgomery, 2005); a review article of a series of studies into the effects of omega-3 on

(7) See Mol (2012) and Vogel and Mol (2014) for some of the complexities to do with food's abilities to make people larger. 
mental health (Hallahan and Garland, 2005); and finally a report on the effects of omega-3 on a single pregnant woman diagnosed with schizophrenia (Su et al, 2001). ${ }^{(8)}$ This move towards the specific is important. To push it even further, here we concentrate on just a single one of these articles, the study of Gesch et al. As Bennett puts it:

"A widely cited 2002 'double-blind, placebo controlled, randomized trial of nutritional supplements on 231 young adult prisoners, comparing disciplinary offences before and during supplementation' shows a 35 percent reduction of offences among British prisoners given omega-3 fatty acids" (2007, page 136).

It is a truly interesting study. While calls to attend 'matter itself' are infused with the hope to bypass epistemology, Gesch et al (2002) have no such illusions. They meticulously specify their methods. When Bennett respectfully notes that Gesch et al engaged in a "double-blind, placebo controlled, randomized trial", she reads these methods as a token of the trustworthiness of their results. Here, we rather wonder what their specificities imply. Gesch et al conducted a trial. Trials are designed to ensure that the effects of an intervention are indeed effects of the intervention, and not of something else. Gesch et al are interested in the effects of providing people with nutritional supplements. In their "double-blind, placebo controlled, randomized trial" they divided their research group into two subgroups. One subgroup received nutritional supplements and the other did not. The term double-blind indicates that neither the participants nor the researchers knew who got supplements and who a placebo. The randomized means that chance alone determined group allocation. All this work gives Bennett reason to conclude that omega-3 fatty acids lead to a $35 \%$ reduction of offences among the prisoners in the study. Gesch et al, however, conclude something slightly different.

First, the article supplies an additional fact: "Both omega-6 and omega-3 essential fatty acids have been found to be deficient among violent offenders" (Corrigan et al, 1994 in Gesch et al, 2002, page 23). This underscores that the trial was conducted in a specific subgroup of people. All participants were violent offenders and therefore likely to have an omega-3 (and an omega-6) deficiency. These deficiencies made the researchers think that it would be advisable to include fatty acids in their study of the effects of supplements:

"For this reason, an essential fatty acid supplement was also employed. 'Efamol Marine' provides omega- 6 and omega-3 essential fatty acids without an obvious after taste, a factor that could otherwise have compromised the blind" (Gesch et al, 2002, page 23). The precise dose and ingredients are specified. It was "four capsules providing $1260 \mathrm{mg}$ linoleic acid, $160 \mathrm{mg}$ gamma linolenic acid, $80 \mathrm{mg}$ eicosapentaenoic acid and $44 \mathrm{mg}$ docosahexaenoic acid" (Gesch et al, 2002, page 23).

We also learn how it is that the placebo group was properly deceived into thinking that their pills, too, might contain essential fatty acids. They were given "A vegetable oil-based placebo of identical colour and clear gelatine shell" (Gesch et al, 2002, page 23). But fatty acids were not the only food supplement the intervention group received. The Efamol Marine was added to a capsule of Forceval. Table 1 (adapted from the article, Gesch et al, 2002, page 23) specifies what each Forceval capsule contains:

This long list suggests that the $35 \%$ reduction of offences among the participants who received true supplements (and not a placebo) might have been due to the omega-3, but there are many other possibilities. The improvement might also have been due to the omega- 6 or any of the above vitamins and minerals; or the secret might lie in their combination. This is no problem for Gesch et al, for their interest is in the effects of supplements. However, it is a

${ }^{(8)}$ Bennett also quotes another article we had to leave out of our analysis as we did not manage to find it: Carroll, 2004, "Diets heavy in saturated fats may lead to fading memories" Neurology Today 4(12) 31-32. 
Table 1. Vitamins and minerals in one 'Forceval' capsule (adapted from Gesch et al, 2002, page 23)

\begin{tabular}{|c|c|c|c|c|}
\hline Nutrient & Potency & UK RNIs $^{\mathrm{b}}$ & EU RDAs & US DRIs $^{\mathrm{c}}$ \\
\hline $\operatorname{Vitamin} \mathrm{A}(\mu \mathrm{g})^{\mathrm{a}}$ & 750 & 700 & 800 & 900 \\
\hline Vitamin D $(\mu \mathrm{g})$ & 10 & - & 5 & 5 \\
\hline Vitamin B1 (mg) & 1.2 & 1 & 1.4 & 1.2 \\
\hline Vitamin B2 (mg) & 1.6 & 1.3 & 1.6 & 1.3 \\
\hline Vitamin B6 (mg) & 2 & 1.4 & 2 & 1.3 \\
\hline Vitamin B12 $(\mu \mathrm{g})$ & 3 & 1.5 & 1 & 2.4 \\
\hline Vitamin C (mg) & 60 & 40 & 60 & 90 \\
\hline Vitamin E (mg) & 10 & - & 10 & 15 \\
\hline Vitamin K1 $(\mu \mathrm{g})$ & - & - & - & 120 \\
\hline Biotin $(\mu \mathrm{g})$ & 100 & - & 150 & 30 \\
\hline Nicotinamide (mg) & 18 & 17 & 18 & 16 \\
\hline Pantothenic acid (mg) & 4 & - & 6 & 5 \\
\hline Folic acid $(\mu \mathrm{g})$ & 400 & 200 & 200 & 400 \\
\hline Calcium (mg) & 100 & 700 & 800 & 1000 \\
\hline Iron (mg) & 12 & 8.7 & 14 & 8 \\
\hline Copper (mg) & 2 & 1.2 & - & 0.9 \\
\hline Magnesium (mg) & 30 & 300 & 300 & 400 \\
\hline Zinc (mg) & 15 & 9.5 & 15 & 11 \\
\hline Iodine $(\mu \mathrm{g})$ & 140 & 140 & 150 & 150 \\
\hline Manganese (mg) & 3 & - & - & 2.3 \\
\hline Potassium (mg) & 4 & 3500 & - & - \\
\hline Phosphorus (mg) & 77 & 550 & 800 & 700 \\
\hline Selenium $(\mu \mathrm{g})$ & 50 & 75 & - & 55 \\
\hline Chromium $(\mu \mathrm{g})$ & 200 & - & - & 35 \\
\hline Molybdenum ( $\mu \mathrm{g})$ & 250 & - & - & 45 \\
\hline
\end{tabular}

RNI, reference nutrient intake; RDA, recommended daily intake; DRI, daily recommended intake.

${ }^{a}$ Retinol equivalent from intake of $\beta$-carotene.

${ }^{\mathrm{b}}$ UK RNI for 19 to 50 -year-old males.

${ }^{c}$ US DRI 19 to 30-year-old males. The values in italics have no US DRI and are defined as adequate intakes (AI). The figures in normal type are US DRIs.

problem for Bennett since she cites the article to make a claim about omega-3 - in isolation. She quotes Gesch et al as saying that "omega-3 fatty acids can make prisoners less prone to violent acts". But this is going too fast. Bennett prudently adds that "results such as these are always subject to further research" (2010, page 41), but our point does not have to do with the provisional character of scientific facts. It is rather that the results of scientific research cannot be so easily disentangled from the methodological specificities of the original research and the relations in which these enmesh the substances explored.

The techniques of the double-blind randomised trial make it possible to investigate the effects of dietary supplements on research participants. However, these techniques are demanding. They cannot be put to work just anywhere: they depend on a setting in which potentially 'intervening variables' are amenable to control. Originally, trials were invented to study the strong effects of drugs that were expected to overrule the much weaker effects of other elements in people's lives, such as what they ate, how long they slept, or how much exercise they took. However, the effects of dietary supplements are not necessarily a lot stronger than those of 'ordinary' food and drink. In addition (and this is one of the intractable problems of nutrition science), the various substances that people ingest tend to affect each other. 
This means that it is helpful to know what people are eating. Here the prison comes in. Doing research in a prison provides researchers with an exceptional degree of control. This is not to say that Gesch et al (2002) have exploited judicial power to put their research participants on strictly controlled diets. Such things have been done, but in the present case the control had to do with knowledge. With some added work (their own as well as that of the prisoners), Gesch et al could account for what everyone ate.

"The dietary intake of the participants was assessed using 7-day food diaries.... As all foods consumed by prisoners originated in the prison, it was possible to devise a diary where the participants indicated which of the available choices they had eaten and how much (a quarter, a half, three quarters of a portion, all or a second portion). Portion weights were determined from the serveries. They were asked to report the number of items consumed, including spread on bread and milk and sugar in beverages. A list of food items (eg, chocolate) that could be purchased from the prison shop was also included to record consumption. The quantity and type of all food consumed was entered into a computer package ('Superdiet') for each of the 7 days" (2002, pages 23-24).

The researchers used the carefully assembled diary facts, in combination with a data base that reports the amount of nutrients in all kinds of foods, to assess the total nutrient intake of their research participants. "The nutrient content of each prisoner's diet was determined using a database based on McCance and Widdowson's 'The Composition of Foods" (Holland et al, 1996 in Gesch et al, 2002, page 23).

Prison life also provided Gesch et al with one of their parameters of effect. First, to allow comparison with the results of other studies, the researchers used a set of 'reliable and validated' psychological tests to measure the effects of the supplements.

"The following measures were employed: verbal ability and intelligence derived from the General Aptitude Test Battery (USES 1967); emotional control from the Emotional Control Questionnaire (Roger and Nesshoever, 1987, Roger and Najarian, 1989); measurement of anger and aggression from the Survey Anger Scales (O'Rourke, 1994); self-reported health status from the Malaise Inventory (Rutter et al, 1970); and the Hospital Anxiety and Depression Questionnaire (Zigmond and Snaith, 1983). The reliability and validity of these measures have been demonstrated previously (Bramley et al, 1988)" (Gesch et al, 2002, page 23).

However, in addition to these tests, which might be used in any population willing and able to fill in forms or answer questions, the prison offered something else: a way of bypassing people's self-assertions and of directly measuring their deeds. For the prison keeps records of the transgressions of its rules, both serious and minor.

"Antisocial behaviour resulting in disciplinary action was adjudicated through Governor and minor reports. Governor reports adjudicate more serious incidents such as those involving violence and may involve loss of remission. Minor reports typically adjudicate on a failure to comply with requirements" (Gesch et al, 2002, page 23).

So the behaviours recorded by the prison administration are undesirable: for example, acts of violence and failure to comply with requirements. As the researchers were allowed to use prison records, they were able to conclude that the effects of the supplements included a remarkable $35 \%$ reduction of offences.

It is possible to say, as Bennett does, that these findings "support the idea that lipids have the power not just to increase human flesh but also to induce human moods, modes of sociality and states of mind" (2007, page 137). But our analysis suggests that this may be too rough, ready, and general. It misses out on the complexities of the case. First, Gesch et al (2002) did not study 'humans' in general, but people who probably had an omega-3 deficiency to begin with. That this might be important is clear if we imagine a study of people 
with a calorie deficiency. A study like that might well find that just about any food, and why not a serious bag of chips, would improve their mood and sociality. ${ }^{(9)}$ The implication is that what is special about omega-3 may be not so much that it affects human beings, but rather that it is more expensive than chips. Second, as we have seen, the positive behavioural effects that Gesch et al found may have been due to the omega-3, but they may also have been due to any of the other ingredients in the supplements - or their interaction. For Gesch et al this was not particularly relevant, but it is for the rest of the world (see the next section). Third, it is relevant that the study quoted was done in a prison. The point here is not that this gave the researchers excessive power over their research subjects. History is full of examples where research in prisons included coercion. ${ }^{(10)}$ In the present context, however, we want to make an altogether different move. That is to say that its prison context provides the research of Gesch et al with its soul. For if prisoners become less aggressive when they receive food supplements, this suggests that, in the ordinary course of events, their food is deficient. More strongly still, it underscores that malnutrition is a wider problem, for even if among poor populations (from which inmates tend to be recruited) there are many large individuals, they may still be malnourished. Their intake of micronutrients may fail to meet their needs. One might say: many people who have ample access to chips, which are cheap, do not necessarily get to eat enough vitamins, minerals, and essential fatty acids, if only because these are contained in foods that are expensive. Or, as it is summarised in the review article that Bennett quotes: "antisocial behaviour in prisons, including violence, are reduced by vitamins, minerals and essential fatty acids with similar implications for those eating poor diets in the community" (Hallahan and Garland, 2005). Suddenly it appears that the banal and the spectacular are all too closely intertwined. The concern of Gesch et al is not with the general issue that materialities are active, but more specifically, with what good foods might do for those who currently lack them. Their research was not designed to feed into political theory, but to inform political practice.

All of which goes to show that, when we go beyond just assembling the conclusions of scientific articles, and take the trouble to unravel their methodological intricacies, it appears that scientific research has little to say about matter itself. Instead, it explores matter engaged in relations and, crucially, helps to practically mediate such relations. Researchers seek out a research setting (here, a prison); procure stuff (here, food supplements and placebos); administer interventions (here, by asking their research subjects to ingest supplements or a placebo); control for other variables (here, by translating everyone's complete food intake into nutrient language); and measure outcomes (here: by asking research subjects to fill in forms and by monitoring the prison's administration of transgressions), all the while responding to, and helping to raise, concerns (here, about malnutrition) ${ }^{(11)}$. If all these efforts would suggest that 'omega-3 acts', then such action would still not be essential to omega-3 itself, for throughout the research process omega-3 is never alone. Whatever it does, it does in conjunction with other entities, enmeshed in a variety of relations. ${ }^{(12)}$

${ }^{(9)}$ For wartime histories of calorie deficiency and food rationing, see Heim (2008). For global hunger, see Beuchelt and Virchow (2012).

${ }^{(10)}$ There is a painfully rich history of moments where clinical trials on inmates have gone wrong; see, for example, Fitzpatrick (2012). For further overall insights into prison life, see Rhodes (2004).

${ }^{(11)}$ As to the power of researchers: note that, at almost every turn in this methodological chain, the research subjects might easily refuse to collaborate or subtly subvert the research. For the issue of the active participation of research subjects in research, see Epstein (1996) and Shapin (2010).

${ }^{(12)}$ Here, we leave out many such relations. There is, for example, also research that suggests that what matters most for humans is not the overall amount of omega- 3 they ingest, but rather the ratio between their omega-3 and omega- 6 intake. Obviously, here our point is not to affirm or reject health claims, but to stress the specificities involved in making them. 


\section{Where omega-3 comes from}

While she explores the character of edible matter, Bennett beautifully evokes the mutually transformative relation between food and eater.

"If the eaten is to become 'food', it must be digestible to a formerly foreign body. Likewise, if the eater is to be nourished, it must accommodate itself to a formerly foreign body. Both, then, have to have been mutable, to have always been a materiality that is hustle and flow as well as sedimentation and substance" (Bennett, 2007, pages 134-135). This is again an insight that we fullheartedly endorse. However, even if it is true that, in eating, substances that were 'formerly foreign' come to be implicated in each other, a caveat is needed. This particular relation is not symmetrical: while one participant eats, the other is being eaten. ${ }^{(13)}$ What follows from this asymmetry? Bennett draws attention to the activity of the stuff being eaten: "lipids have the power to induce human moods, modes of sociality and states of mind" (2007, page 137). Here we would like to explore the activities of the eaters. This may seem humanist as it brings human agency rather than fatty agencies to the fore. However, it also implies a shift in attention away from the human moods affected by omega-3 and onto the worlds from which omega-3 is procured.

Which worlds might this be? We quote from another research article: "At present, human dietary intake of omega-3 oils is largely derived from the flesh of marine pelagic oily fish, such as mackerel, salmon, anchovy, sprat, pilchard and herring" (Brunner et al, 2009, page 94). Some people ingest 'essential fatty acids' that come from walnuts and other plant resources. But Brunner et al suggest that the bulk of the omega-3 currently eaten by people comes from fish. In order to spell out what this leads on to, Brunner et al did not engage in experimental research. Their method is a different one. It is to assemble existing numerical data from a variety of sources and adding these together in a meaningful way. Obviously, all the data they use might be unpacked. There are likely to be flaws, miscalculations, ambivalences, and so on. The way Brunner et al relate their facts, likewise, is amenable to further scrutiny and analysis. Somewhat asymmetrically we do not engage in such unpacking here. For our present purposes, what we care about most are not the research outcomes so much as the questions about 'matter' that Brunner et al ask. These we would like to introduce into the discussion around new materialism.

Brunner et al (2009) ask questions to do with fish being eaten as food and fish being dried or distilled and transformed into pills. At first glance, eating fish or fish pills may seem ecological routine. Creatures 'naturally' relate to each other by feeding and eating. Plants are eaten by herbivores and omnivores; animals may be prey for predators; and as they die, all organisms become the foodstuff of decomposers. The drawings of idealised ecosystems turn these manifold relations into food webs. And then, in food cycles, they show fluctuating lines that reflect cyclic patterns of relating (if the prey population grows, so does that of the predator, which implies that more prey is eaten, hence the prey population dwindles, which starves off a proportion of the predators, and so on). However, if you were to make a drawing based on the numbers Brunner et al have assembled, such fluctuating balances would be nowhere in sight. Instead, fish numbers move rapidly downward.

"Recent assessments indicate that we have reached the point at which over three quarters of fish stocks are fully exploited (52\%) or overfished (24\%). In the NE Atlantic the proportion of stocks considered to be within 'safe biological limits' fell from $26 \%$ to 16\% between 1996 and 2001. Unless the current trajectory is altered decisively, human predation is predicted to lead to complete collapse of all economically important species

${ }^{(13)}$ Leaving aside exceptions, such as parasites ingested that in turn eat from the body of their human host, which here we keep out of the equation. 
by the mid-21st century, potentially causing irreversible damage to marine ecosystems"

(Brunner et al, 2009, page 95).

If omega-3 is sourced from fish for human consumption, this may, in the short term, improve our moods, but in the slightly longer term it depletes the oceans. In the process not all human beings are affected equally. This is one of the concerns that Brunner et al, publishing in an epidemiology journal, address. They signal that 'official recommendations' currently admonish people in rich countries to care about their fatty acids and eat more fish. In line with this, demand rises. This makes things yet more difficult than they already were for those living on the sea shores of the poorer parts of the world. "Overfishing undermines food security by reducing the supply of a vital source of dietary protein, particularly in the coastal regions of less economically developed countries" (Brunner et al, 2009, page 96). Often such tensions remain hidden, as the provenance of our foods remains opaque, but sometimes they are made public — and not just in academic journals. ${ }^{(14)}$

In 2010 Swedish television showed a documentary about local fisheries off the shores of occupied Western Sahara. ${ }^{(15)}$ The filmmakers followed trucks filled with the catch of the day. The fishermen had said that these would go to the local market, but instead they went to the city of Layonne where the Norwegian corporation KB Fish transformed their contents into fish oil, which it shipped off to Norway. This is one of the ways the health industry acquires the omega-3 that it puts into capsules for the Scandinavian market. At the same time, Swedish charity organisations send canned mackerel from Thailand to Western Sahara, as the local population (whose local fish is shipped off to the North) does not have enough food to make it through the day. As these sad ironies became public, the company Life announced that it would cut ties with the Western Saharan supplier: " "For all other Omega 3 products, we will ensure with all suppliers that we receive appropriate documentation and guarantees' says Thomas Johansson, marketing director at Life." ${ }^{(16)}$ It is to be applauded that this company wants to take responsibility for its resourcing, but there may be an irreducible problem here. What kind of documentation and guarantees might Johansson be looking for? Where might a Swedish food supplement company find fish for omega-3 from stocks that are strong enough to feed local populations, supplement Swedes, and still survive the assault?

There are no easy solutions for the varied politics implied here. And it may well be that, overall, Bennett's (2010) call to attend to the liveliness of 'matter itself' is a positive contribution, as at least it underscores the relevance of political ecology. ${ }^{(17)}$ However, in its specificities, or rather in its neglect of specificities, this call misses a crucial point, namely, that omega-3 is not so much 'matter itself' as 'matter related'. There is omega-3 in plants, but under current market conditions the stuff being sold comes by and large from fish. And this fish, in its turn, is not 'fish itself', but 'fish-related' too. It relates to the environmental and climatic changes that transform its habitat. It relates to the zooplankton and smaller fish that it eats, and to the other species (including human beings from various parts of the world) that feed on it. And as human eaters organise themselves in complex sociomaterial ways, the fish that they eat has become entangled with long-distance trade routes; laws to

${ }^{(14)}$ In most places where omega- 3 and its potential health benefits are made present, the fish and fisheries that it comes from are absent [see Callon and Law (2004)]. For an analysis of how packaging, labelling, and materiality of meat are made to matter in food consumption practices, see Evans and Miele (2012).

${ }^{(15)}$ Here we leave Brunner et al (2009) and mobilise materials that filmmakers and journalists put in the public domain.

(16) http://www.wsrw.org/a105x1365

(17) For a discussion of the politics of Bennett's book, see the reviews by Anderson (2011), Abrahamsson (2011), Braun (2011), Gregson (2011), Hinchcliff (2011), and the response by Bennett (2011) in Dialogues in Human Geography $1390-406$. 
do with who is and who is not allowed to catch fish, and where; ways of ducking these laws; huge disparities in technological and other resources; ironic juxtapositions of (what might be glossed as) theft and (what is applauded as) aid. ${ }^{(18)}$ All of which suggests that, rather than getting enthusiastic about the liveliness of 'matter itself', it might be more relevant to face the complexities, frictions, intractabilities, and conundrums of 'matter in relation'. For it is in their relations that matters become political, whether those politics are loudly contested or silently endured. It is here that the question arises of which relations to foster and in which direction to go. ${ }^{(19)}$

\section{On modes of doing}

Bennett talks about omega-3 without directly concerning herself with such contentious issues as the inequalities between well-fed and undernourished people or the startling depletions of fish stocks worldwide. This would be fine if bracketing these concerns for the moment were a good way of elucidating nonhuman agency. But it is not. Rather, forgetting about research contexts or the question of where matters (such as omega-3) come from introduces misunderstandings about agency. For severing the relations in which figures are enmeshed ties in with liberal notions that suggest that 'acting' is a capability of individual entities. Situating omega-3 in its contexts brings to the fore that 'doing' is a distributed achievement. Ironically, the first provocative uses of the term 'agency' for 'things' were intended to bring out the distributed character of all doings. Early actor-network theory argued that no actor ever acts alone, as all actors depend on the network of which they are a part and that they help to form. ${ }^{(20)}$ At some point in the discussion, that distributed character of all doings seems to have been lost, while the term 'agency' remained. Here, we would like to insist on the enduring relevance of relations and raise the question whether 'agency' is, after all, such a good term for the propensity of entities that are involved in 'doing'.

Let us take a step back. In the Western philosophical tradition there is a long-standing dichotomy between understanding events as being caused by external forces and understanding events as creative acts. Causal relations were presumed to reign in the material world and to be studied by the natural sciences. ${ }^{(21)}$ Human beings, by contrast, were free to act. ${ }^{(22)}$ In the public realm this freedom was stipulated by the rule of law. With the waning of feudalism, political subjects had acquired rights in relation to the state, while, within limits, they were entitled to sell their labour power on the market. In courts, free subjects had to answer for their deeds, which were taken to follow on from their choices. Hence, if the natural sciences explored the laws of nature, state laws addressed human subjects as free agents. Over time, this idealised scheme has been messed with in many ways. For instance, the human sciences have had trouble fitting in. Should they seek causal explanations of people's 'behaviours' and in the process sideline freedom as an illusion? Or should they rather ask people to explain the reasons for their choices? At the same time, in the natural sciences causal explanations also hit their limits. Quantum physics, the chemistry of dissipated states, and the sciences

${ }^{(18)}$ For work in anthropology that fosters sensitivities to global commodity chains, see Tsing (2004). For geographically studied food chains, see Leslie and Reimer (1999) and Jackson et al (2006).

${ }^{(19)}$ See Barry (2001) for an analysis of the various ways in which materials become political, rather than always already being so.

${ }^{(20)}$ For examples, see Akrich (1992), Callon (1986), and Latour (1987). And, for a much later take, Law and Mol (2008)

${ }^{(21)}$ For a great analysis of causal explanations, see Latour (1988).

${ }^{(22)}$ This came with all kinds of conditions. Women, noncitizens, children-highly varied groups were legal subjects only in some contexts and to some extent. This is an added complexity that we leave out here. 
of complex systems, each in their own ways, have topicalised situations in which matter behaves in unpredictable ways. ${ }^{(23)}$ Exit determinism.

But does the unpredictable character of matter imply that the legal version of the world fits things better? How appropriate is it to say that matters act? At this point we have our doubts. Maybe it is not wise to spread liberal dreams about 'acting', infused as they are with civic notions of freedom and choice, from humanity to the rest of the world. Take the case of omega-3. Bennett introduces this to illustrate nonhuman agency, but she draws on research that explores causal links. The methods that Gesch et al (2002) use are designed to study effects, here the effects of nutritional supplements. These effects are supposed to work behind the backs of the humans involved. Typical in this respect is the following precaution:

"At the end of the trial, participants were asked to complete and sign a form recording whether they thought they had received active or placebo supplements; a total of 97 did so. The proportions of those that guessed correctly in the active and placebo groups were very similar and did not differ from that expected by chance" (Gesch et al, 2002, page 25$)^{(24)}$.

Gesch et al (2002) take the ignorance of their research participants to be proof of the efficacy of the supplements. For, if people had guessed right, their own ideas about themselves might have changed, and this might have led them to act differently. However, as people 'cannot tell', it must be the pills that caused the improvement in behaviour of those who took them. It is an intriguing example of how human sciences may navigate between, or combine, determinist and freedom language in their understanding of human beings. But what is relevant for the present purpose, is that Bennett apparently calls upon research that proves the causal effects of supplements in order to argue that these nonhuman matters act.

The clash is flagrant. But, then again, research methods designed to determine causal effects and liberal theories of action have something in common. They both isolate primary entities (effectors, actors) from their secondary contexts (confounding variables, mitigating circumstances). Gesch et al's (2002) meticulous counting of the complete dietary intake of the prisoners is meant to do just that: reckon with and calculate away the influence of potentially confounding variables. This effort at purification resembles that of a judge seeking to know if an offender indeed acted out of his own free will or was prompted by other people or circumstances. Here, we are questioning the pertinence of such isolating techniques. Things, so we seek to stress, neither 'cause' effects nor 'act' all by themselves. Materialities work in concert; they are relational. Omega-3 does not decrease aggression in humans all by itself. It may contribute to such a decrease, but if it does, it does so (if we follow Gesch et al) in combination with vitamins and minerals, and in people who start out with a micronutrient deficiency. And as long as fish caught in the South are used as the main source of the omega-3 pills sold in the North, any potential improvement of the moods of some human beings comes at the cost of other human beings who come to lack in proteins or even outright starve. The fish are killed one way or the other. In the long term, the problem here is that of the stock or the ecosystem: if too many fish are killed, fish stocks dwindle and ecosystems impoverish or collapse. Neither causality nor agency seems very well suited to describe what is going on here. It would be better to explore other verbs for the varied relevant modes of 'doing'.

${ }^{(23)}$ In the early 1980s this was beautifully laid out by, for example, Prigogine and Stengers (1984) and Gleick (1987).

${ }^{(24)}$ For reasons of readability we took out various additional specifying numbers from this quote, as they are not relevant in the present context. 
Some scholars have started to engage in this. For example, doings have been topicalised as affordances and responses. ${ }^{(25)}$ Take a festive occasion in Sweden or the Netherlands. Food is laid out on a table and a nicely prepared fish dish affords the guests the possibility of eating it. Some may indeed gratefully respond to this invitation by doing so. However, eating is not an effect of food, for some guests do not like fish, are vegetarian, not hungry, or in the mood for potato salad. Affordance is not causality. At the same time, responding is not a free choice, for it is situated and relational. After all, you may respond by eating fish only when fish has been dished up in the first place. Terms like affordances and responses allow for quite different analyses than seeking causes or actions. And so, too, do other terms that stipulate doings, for instance, caring and tinkering. ${ }^{(26)}$ These particular terms attune to the reality that future events are often unpredictable. For you may 'choose' to eat fish or to take omega-3 supplements in the hope that you will lower your aggressive tendencies, but the desired effects may never occur. Your mood may behave in intractable ways. This becomes slightly less frustrating if you stop dreaming about effects following on from causes or about choices that offer control. Being open to the erratic may help you to figure out experimentally and caringly which foods are good for you under which circumstances, while accepting that unexpected things may happen along the way. If they do, you may adapt, try again, and keep on tinkering.

A final mode of doing that we want to mention here is eating. ${ }^{(27)}$ As Bennett notes, eating engenders and indexes mutability. Metabolic processes turn one figure into another. For instance, if you were to eat food containing omega-3, this particular fatty acid might enter your bloodstream, if your bowels indeed accepted it. In the process of chewing, digesting, and absorbing, the omega-3 loses its entanglement with fish (or walnuts!) and becomes a part of you. But if subsequently your mood were to improve, to what or whom might you give credit? To you, yourself, as you were the actor eating? Or to the omega-3, as its metabolic products found a way of binding to some crucial receptor? Perhaps, in the latter case, you are still the relevant actor after all, since the omega- 3 that you ate has become a part of 'you'. ${ }^{(28)}$ Which suggests that, all in all, omega-3, absorbed and transformed into a part of a human body, is a very peculiar example of nonhuman agency. For, as a mode of doing, eating crucially includes transforming: food into eater and eater into a well-fed rather than an undernourished creature. But, as it is through eating and feeding that diverse beings or substances fuse, in the end you never quite know who or what has done it. Has omega-3 acted, or, since you absorbed it, have you? Eating interferes with 'doing' in a fascinating way not just by relating the creatures and substances that 'do', but also, crucially, irreversibly, by transforming them - and their agential abilities.

\section{Conclusion}

Bennett (2010) (in line with most new materialists) insists on the relevance of nonhuman agency. She does so in a laudable attempt to sensitise political theory to material forces. This is highly relevant now that a range of ecological crises are looming, and it is because we share Bennett's overall concerns that we have sought to push the conversation. Our argument is that, if matters act, they never act alone. Relational materialism is in order. In this context

${ }^{(25)}$ This has been done, by Despret (2004), in the context of behavioural research and animal and human psychology.

${ }^{(26)}$ See, for example, Mol (2008a) and Mol et al (2010) for analyses of care in practice.

${ }^{(27)}$ On eating and various versions of doings, see, for example, Abrahamsson (2014), Abrahamsson and Bertoni (2014), Landecker (2013), and Mol (2008b). Crucially (a point left out of the current analysis), eating and feeding are understood and organised in different ways by different people. See, among the extensive anthropological literatures, Strathern (2012), and Bonelli (2014).

${ }^{(28)}$ See Rotman (2008) for more on a bounded you and a 'you' out of bounds. 
the general claim that 'things have politics' has become too vague. This once helped in arguing that technological artefacts are not just modest means by which to achieve external goals, but active mediators that mess with the goals that human beings set themselves to begin with. ${ }^{(29)}$ However, as 'things' have widened from the category of technological artefacts and have come to include all possible materialities, it makes more sense to say that in political practices 'things' figure variously. And the scientific practices that seek to explore what matters do help to shape the realities they study. Take Gesch et al (2002). These authors do not just find that food supplements are effective, but have gone to a lot of practical trouble to make such effects visible. Their work emerges from, and strengthens, the concern that, as long as their food is deficient in micronutrients, prisoners and other poor people are all too easily blamed for 'making the wrong choices'. In their turn, Brunner et al (2009), whom we quoted when discussing where omega-3 comes from, are concerned not with the diets of the poor (or for that matter the rich) in countries in the North, but with the food supplies of people in the South, particularly those in coastal regions who rely on fish for their survival. In addition, Brunner et al bring the fish themselves into the equation. They are worried about global fish stocks that are declining rapidly and at risk of collapsing beyond redemption.

Would such diverse problems be easier to address if matter was explored not on causal terms, but in terms of nonhuman agency? The case of omega- 3 suggests that maybe the core problem is not who or what is credited with the ability to act. It is rather that the various 'goods' and 'bads' at play push and pull in different directions. For if all people in the North did indeed obtain easy access to fatty fish or fish-based omega-3 supplements, this would come at the cost of the coastal inhabitants of the South. And if huge fishing trailers continue to mine the oceans, before long the graphs of fish stocks will hit the $x$-axis. Hence, the issues at stake are relational, too. And the key point is not so much that materialities are involved in political conundrums, but how they are involved. ${ }^{(30)}$ This is best expressed with other verbs than 'causing' and 'acting'. What do the circumstances afford and which responses should be considered; which plants might provide which crucial micronutrients? How to best care for human beings but also for other creatures? How to tinker towards eating well and growing food in sustainable ways? ${ }^{(31)}$ Granted, we have no ready-made answers to any of these questions either. Our meagre contribution is to insist that, in all their specificities, these are the questions that deserve to be confronted. A relational world is complex and messy. But in one way or another, given how many we are, human eating depends on caring well for our food. Rather than dreaming that omega-3 will improve our moods, we would do well to seek long-term ways to live with it. ${ }^{(32)}$

Acknowledgements. We would like to thank Jane Bennett for drawing attention to materialities in political theory and for the case of omega-3. This paper was made possible by an ERC Advanced Grant (AdG09 Nr. 249397) financing the study of Eating Bodies in Western Practice and Theory. Thanks for their comments and support to the rest of the 'Eating bodies' team: Emily Yates-Doerr, Else Vogel, Cristobal Bonelli, Anna Mann, and Tjitske Holtrop. Thanks also to John Law and Christian Abrahamsson for encouragements, critique, editing, and literature advice. Finally, we would like to thank the two anonymous reviewers of this journal for their helpful remarks.

${ }^{(29)}$ See Latour (2002b) for the means-ends confusion and Abrahamsson and Bertoni (2014) for an analysis of how the goals of humans may also be disrupted by earth worms and other organisms.

${ }^{(30)}$ Among the many good studies that explore materialities and some of their goods and bads in a relational way, see, for example, M'charek (2013), Pols (2010), and Beisel and Schneider (2012).

${ }^{(31)}$ See, for example, Lang (2004). For the difficulties of improving global eating through the use of insects, see Yates-Doerr (2014).

${ }^{(32)}$ For the notion of 'living with' that this paper hinges on, see Haraway (2010). 


\section{References}

Abrahamsson S, 2014, "An actor-network analysis of constipation and agency: shit happens" Subjectivity 7 111-130

Abrahamsson C, 2011, "Book review forum. Vibrant Matter: A Political Ecology of Things" $1399-402$

Abrahamsson S, Bertoni F, 2014, "Compost politics: experimenting with togetherness in vermicomposting" Environmental Humanities 4 125-148

Akrich M, 1992, "The de-scription of technical objects", in Shaping Technology/Building Society Eds W Bijker, J Law (MIT Press, Cambridge, MA) pp 205-224

Alaimo S, Hekman S H, 2007 Material Feminisms (Indiana University Press, Bloomington, IL)

Anderson B, "Book review forum. Vibrant Matter: A Political Ecology of Things" Dialogues In Human Geography $1393-396$

Barry A, 2001 Political Machines: Governing a Technological Society (Athlone Press, London)

Beisel U, Schneider T, 2012, "Provincialising waste: the transformation of ambulance car 7/83-2 to tro-tro Dr.JESUS" Environment and Planning D: Society and Space 30 639-654

Bennett J, 2007, "Edible matter" New Left Review 45 133-145

Bennett J, 2010 Vibrant Matter: A Political Ecology of Things (Duke University Press, Durham, NC)

Bennett J, 2011, “Author response" Dialogues In Human Geography 1 404-406

Bertoni F, 2011, "Turning to speculation?” Krisis 3 74-79

Beuchelt T, Virchow D, 2012, "Food sovereignty or the human right to adequate food: which concept serves better as international development policy for global hunger and poverty reduction?" Agriculture and Human Values 29 259-273

Bonelli C, 2014, "What Pehuenche blood does: hemic feasting, intersubjective participation, and witchcraft in Southern Chile" Hau: Journal of Ethnographic Theory 4 105-127

Braun B, 2011, "Book review forum. Vibrant Matter: A Political Ecology of Things" Dialogues In Human Geography 1 390-393

Brunner E J, Jones P J S, Friel S, Bartley M, 2009, "Fish, human health and marine ecosystem health: policies in collision" International Journal of Epidemiology 38 93-100

Bryant L, Srnicek N, Harman G, 2011 The Speculative Turn: Continental Materialism and Realism (re.press, Melbourne)

Callon M, 1986, "Some elements of a sociology of translation: domestication of the scallops and the fishermen of St Brieuc Bay", in Power, Action and Belief: A New Sociology of Knowledge? Ed. J Law (Routledge, London) pp 196-223

Callon M, Law J, 2004, "Introduction: absence-presence, circulation, and encountering in complex space" Environment and Planning D: Society and Space 22 3-11

Connolly W E, 2013, "The 'new materialism' and the fragility of things" Millennium: Journal of International Studies 41 399-412

Coole D H, Frost S, 2010 New Materialisms: Ontology, Agency, and Politics (Duke University Press, Durham, NC)

Despret V, 2004, "The body we care for: figures of anthropo-zoo-genesis" Body and Society $10111-134$

Dolphijn R, Van der Tuin I, 2012 New Materialism: Interviews and Cartographies (Open Humanities Press, Michigan, MI)

Epstein S, 1996 Impure science: AIDS, activism, and the politics of knowledge (University of California Press, Berkeley, CA)

Evans A B, Miele M, 2012, "Between food and flesh: how animals are made to matter (and not matter) within food consumption practices" Environment and Planning D: Society and Space $30298-314$

Fitzpatrick C, 2012, “The prisoner's dilemma: the history, ethical dimensions, and evolving regulatory landscape of clinical trials on inmates", http://nrs. harvard.edu/urn-3:HUL.InstRepos:10985164

Gesch C B, Hammond S M, Hampson S E, Eves A, Crowder M J, 2002, "Influence of supplementary vitamins, minerals and essential fatty acids on the antisocial behaviour of young adult prisoners: randomised, placebo-controlled trial" The British Journal of Psychiatry 181 22-28 
Gleick J, 1987 Chaos: Making a New Science (Viking, New York)

Gregson N, "Book review forum. Vibrant Matter: A Political Ecology of Things" $1402-404$

Hallahan B, Garland M R, 2005, "Essential fatty acids and mental health" The British Journal of Psychiatry 186 275-277

Haraway D J, 1991 Simians, Cyborgs, and Women: The Reinvention of Nature (Routledge, New York)

Haraway D, 2010, "When species meet: staying with the trouble" Environment and Planning D: Society and Space 28 53-55

Heim S, 2008 Plant Breeding and Agrarian Research in Kaiser-Wilhelm-Institutes 1933-1945: Calories, Caoutchouc, Careers (Springer, New York)

Henare A, Holbraad M,Wastell S, 2007 Thinking Through Things: Theorising Artefacts Ethnographically (Routledge, London)

Hinchliffee 2, 2011, "Book review forum. Vibrant Matter: A Political Ecology of Things" Dialogues In Human Geography 1 396-399

Jackson P, Ward N, Russell P, 2006, "Mobilising the commodity chain concept in the politics of food and farming" Journal of Rural Studies 22 129-141

Landecker H, 2013, "Postindustrial metabolism: fat knowledge" Public Culture 25 495-522

Lang T H M, 2004 Food Wars: The Global Battle for Minds, Mouths, and Markets (Earthscan, London)

Latour B, 1987 Science in Action: How to Follow Scientists and Engineers Through Society (Harvard University Press, Cambridge, MA)

Latour B, 1988, "The politics of explanation: an alternative", in Knowledge and Reflexivity, New Frontiers in the Sciology of Knowledge Ed. S Woolgar (Sage, London) pp 155-177

Latour B, 2002a, "When things strike back: a possible contribution of 'science studies' to the social sciences" British Journal of Sociology 51 107-123

Latour B, 2002b, "Morality and technology: the end of the means" Theory, Culture and Society 19 247-260

Law J, 2004 After Method: Mess in Social Science Research (Routledge, London)

Law J, Mol A, 2008, “The actor-enacted: Cumbrian sheep in 2001”, in Material Agency Eds L Malafouris, C Knappett (Springer, New York) pp 57-77

Lemke T, 2014, "New materialisms: Foucault and the 'government of things" "Theory, Culture and Society doi:10.1177/0263276413519340

Leslie D, Reimer S, 1999, "Spatializing commodity chains" Progress in Human Geography 23 401-420

Leys B R, 2011, “The turn to affect: a critique" Critical Inquiry 37 434-472

Martin E, 2013, "The potentiality of ethnography and the limits of affect theory" Current Anthropology 54 S149-S158

M'charek A, 2013, "Beyond fact or fiction: on the materiality of race in practice" Cultural Anthropology 28 420-442

Mol A, 2008a The Logic of Care: Health and the Problem of Patient Choice (Routledge, London)

Mol A, 2008b, "I eat an apple: on theorizing subjectivities" Subjectivity 1 28-37

Mol A, 2012, "Mind your plate! The ontonorms of Dutch dieting" Social Studies of Science 43 379-396

Mol A, Moser I, Pols J, 2010 Care in Practice: On Tinkering in Clinics, Homes and Farms (Transcript, Piscataway, NJ)

Pols J, 2010, "Wonderful webcams: about active gazes and invisible technologies" Science, Technology, and Human Values 36 451-473

Prigogine I, Stengers I, 1984 Order Out of Chaos: Man's New Dialogue with Nature (Bantam Books, Toronto)

Rhodes L A, 2004 Total Confinement Madness and Reason in the Maximum Security Prison (University of California Press, Berkeley, CA)

Richardson A J, Montgomery P, 2005, “The Oxford-Durham study: a randomized, controlled trial of dietary supplementation with fatty acids in children with developmental coordination disorder" Pediatrics 115 1360-1366 
Rotman B, 2008 Becoming Beside Ourselves: The Alphabet, Ghosts, and Distributed Human Being (Duke University Press, Durham, NC)

Shapin S, 2010 Never Pure: Historical Studies of Science as if it Was Produced by People with Bodies, Situated in Time, Space, Culture, and Society, and Struggling for Credibility and Authority (Johns Hopkins University Press, Baltimore, MD)

Strathern M, 2012, "Eating (and feeding)" Cambridge Anthropology 30 1-14

Su K-P, Shen W W, Huang S-Y, 2001, "Omega-3 fatty acids as a psychotherapeutic agent for a pregnant schizophrenic patient" European Neuropsychopharmacology 11 295-299

Tsing A L, 2004 Friction: An Ethnography of Global Connection (Princeton University Press, Princeton, NJ)

Viveiros de Castro E, Pedersen M A, Holbraad M, 2014, "The politics of ontology: anthropological positions" Cultural Anthropology January 13, http://www.culanth.org/fieldsights/462-the-politicsof-ontology-anthropological-positions

Vogel E, Mol A, 2014, "Enjoy your food: on losing weight and taking pleasure" Sociology of Health and Illness 36 305-317

Woolgar S, Lezaun J, 2013, "The wrong bin bag: a turn to ontology in science and technology studies?" Social Studies of Science 43 321-340

Yates-Doerr E, 2014, "The world in a box? Food security, edible insects, and 'one world, one health' collaboration" Social Science and Medicine doi: 10.1016/j.socscimed.2014.06.020 